\title{
Axonal pathfinding mechanisms at the cortical midline and in the development of the corpus callosum
}

L.J. Richards
Department of Anatomy and Neurobiology, and the Program in Neuroscience, School of Medicine, University of Maryland, Baltimore, MD, USA

\section{Correspondence \\ L.J. Richards \\ Department of Anatomy and \\ Neurobiology, School of Medicine \\ University of Maryland \\ 685 West Baltimore St. \\ Baltimore, MD 21201 \\ USA \\ Fax: +1-410-706-2512 \\ E-mail: Irich001@umaryland.edu}

Presented at the IV International UNESCO Course on "What the

Developing Cerebral Cortex Tells About the Adult Cortex (and Vice Versa)", Rio de Janeiro, RJ, Brazil, December 3-7, 2001.

Received July 12, 2002 Accepted October 10, 2002

\begin{abstract}
The corpus callosum is a large fiber tract that connects neurons in the right and left cerebral hemispheres. Agenesis of the corpus callosum (ACC) is associated with a large number of human syndromes but little is known about why ACC occurs. In most cases of ACC, callosal axons are able to grow toward the midline but are unable to cross it, continuing to grow into large swirls of axons known as Probst bundles. This phenotype suggests that in some cases ACC may be due to defects in axonal guidance at the midline. General guidance mechanisms that influence the development of axons include chemoattraction and chemorepulsion, presented by either membrane-bound or diffusible molecules. These molecules are not only expressed by the final target but by intermediate targets along the pathway, and by pioneering axons that act as guides for later arriving axons. Midline glial populations are important intermediate targets for commissural axons in the spinal cord and brain, including the corpus callosum. The role of midline glial populations and pioneering axons in the formation of the corpus callosum are discussed. Finally the differential guidance of the ipsilaterally projecting perforating pathway and the contralaterally projecting corpus callosum is addressed. Development of the corpus callosum involves the coordination of a number of different guidance mechanisms and the probable involvement of a large number of molecules.
\end{abstract}

\section{Development of the neocortex and the corpus callosum}

The mammalian neocortex is for the most part a six-layered structure that arises in the dorsal aspect of each of the two telencephalic vesicles. The neocortex is regionally specified into functionally distinct areas that process motor and sensory information. Neu-
Key words

- Midline glia

- Glial wedge

- Glial sling

- Indusium griseum glia

- Perforating pathway

- Corpus callosum rons within the cortical plate first send their axons ventrally under the influence of semaphorin molecules (1) to the intermediate zone (a predominantly fiber layer) where they then choose to project either medially or laterally. Neocortical neurons may connect to neurons in the same hemisphere (intracortical connections), the opposite hemisphere (via the corpus callosum) or subcortically 
(via the internal capsule). Here I will focus on just those axonal projections that cross the midline and form the corpus callosum.

Callosally projecting neocortical axons must make a number of projection changes as they grow towards and innervate their final targets. Each change in trajectory of the axon could be considered as an axonal "choice point" (see below) where the axon uses guidance cues within the environment to change its direction of growth. Callosal

\begin{tabular}{|c|c|c|c|c|}
\hline Gene & $\begin{array}{l}\text { Complete } \\
\text { absence of } \\
\text { the corpus } \\
\text { callosum }\end{array}$ & $\begin{array}{l}\text { Reduction } \\
\text { in size of } \\
\text { the corpus } \\
\text { callosum }\end{array}$ & $\begin{array}{l}\text { Other midline } \\
\text { commissure } \\
\text { defects } \\
\text { present }\end{array}$ & Reference \\
\hline
\end{tabular}

Guidance molecules
DCC
EphB2/B3 (Sek4/Nuk)
Netrin 1
Slit2

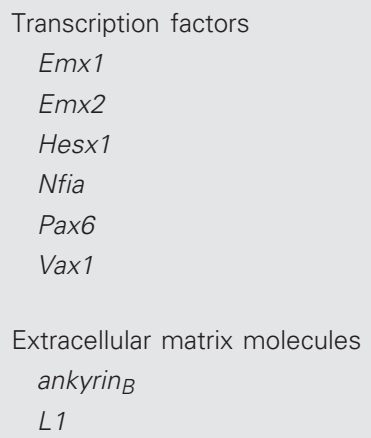

Extracellular matrix molecules $\operatorname{ankyrin}_{B}$

L1

$x$

$x$

$x$

$x$

$x$

Intracellular signaling and cytoplasmic molecules

BAPP
CREB
GAP43
MAP1B
MARCKS
MacMARCKS
Mena
p35/cdk5
p190

Growth factors and related genes

FGF8 $x$
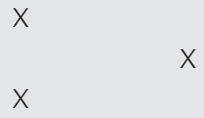

$x$

$x$

$x$

X

X
IGFBP-1

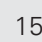

16

8,9

9,10

11

12

13

14

17,18

19

20

21

22

23

24

25

26

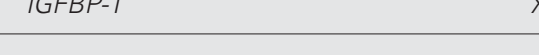

neurons arise primarily from neurons in layers $2 / 3$ and 5 , sending their axon ventrally down into the intermediate zone where they make their first axonal decision to turn and project medially. They then grow toward the midline, enter the cingulate cortex and grow ventrally to the corticoseptal boundary. At the corticoseptal boundary they make a dramatic turn medially to project across the midline, followed by another turn dorsally to project away from the midline and up into the contralateral hemisphere. From here the axon grows within the intermediate zone, through the cingulate cortex and into the neocortex where it will locate the appropriate area of its final target. Once the appropriate region is located the axon turns dorsally to locate the correct target layer and neuron(s) with which to form synapses. Little is known about how each of these axonal guidance decisions are made by callosal axons. Here the focus is on those cues that guide callosal axons toward and across the cortical midline.

\section{Agenesis of the corpus callosum}

In a large number of human congenital syndromes, the corpus callosum fails to form. The most common phenotype is that the axons arrive at the midline but are unable to cross and swirl into longitudinal neuromas called Probst bundles. In humans, agenesis of the corpus callosum (ACC) is always associated with four syndromes: Aicardi, acrocallosal, Andermann and Shapiro syndromes (2). Interestingly ACC with the formation of Probst bundles has also been seen in mice in which specific genes are mutated (see Table 1; Refs. 3-28). These genes do not fit into a single classification of molecule and represent transmembrane molecules, secreted proteins, transcription factors, growth factors and receptors, and intracellular signaling and cytoplasmic molecules. Little is known about how these genes cause ACC or whether these molecules act in synergy or in 
parallel to cause ACC. Future directions in ACC research hope to uncover the answers to these questions.

\section{Axonal guidance mechanisms in the developing nervous system}

After neuronal precursors have undergone migration and differentiation they begin to send out axons that will enable them to connect with their targets either within the central nervous system or within the periphery. This precise connectivity allows the nervous system to function in a coordinated manner. Such precision is only brought about by an exquisitely coordinated series of axonal pathfinding mechanisms that guide growing axons to their final target. These mechanisms include both molecules expressed within the environment of the growing axons and molecules such as receptors expressed by the axons themselves.

Axons often extend over long distances to reach their final targets. Given these distances it is impossible for axons to be guided by target-derived factors alone (29). In order to circumvent this problem axons use guidance molecules expressed by structures along their pathway. Such structures are called intermediate targets. Once reaching an intermediate target, axons often make significant changes in their trajectory at so-called "choice points".

A number of different molecular mechanisms for axonal pathfinding have been described. These include chemorepulsion and chemoattraction (30). That is, axons can be attracted toward a particular target or repelled or inhibited from entering a specific region (Figure 1). Attraction or repulsion of an axonal growth cone (the growing tip of the axon) is mediated by molecules expressed and released from cells (diffusible molecules) or by molecules that remain bound to the cell surface or extracellular matrix (Figure 1). Such "bound" molecules are not freely distributed as is the case for diffusible mol- ecules. A driving hypothesis for how axons are able to sense these molecules in such a manner as to direct their growth is that these guidance molecules are distributed in a gradient, being present at higher concentrations at the source and at progressively lower concentrations away from the source (Figure 1). Axons then direct their growth toward the source, in the case of chemoattraction, by sensing a concentration difference across the width of their growth cone. Evidence for this hypothesis comes from in vitro coculture and pipetting experiments in which axonal growth is directed toward (or away from) either another explant or a pipette containing a guidance molecule $(31,32)$.

In the developing nervous system there are a number of large bundles or tracts of axons that grow in tightly fasciculated bundles toward their target(s). An additional mechanism by which axons locate their targets is by growing along other axons that have previously taken the same path. Such early axons are called pioneering axons (Figure 1). Although the pioneering axons probably use the cues described above, later following axons may fasciculate with the pio-

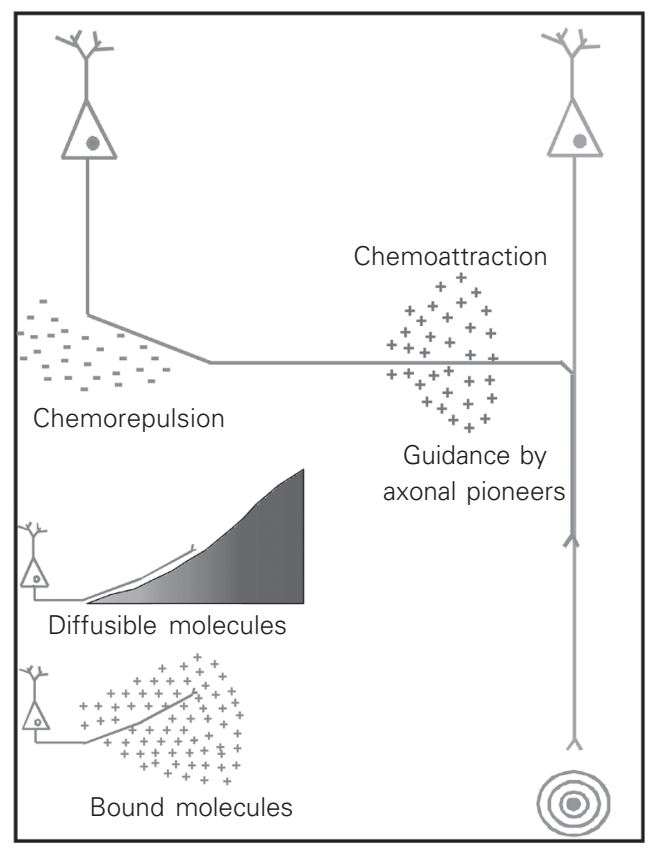

Figure 1. Axonal guidance mechanisms in the developing nervous system. 
neers in order to locate their target. During the formation of large axonal tracts, a few axons grow along the pathway first, followed by more and more axons as development proceeds, rather than the entire axonal tract forming at the same time. It is therefore likely that later following axons recognize molecules on the surface of the pioneers that allow them to fasciculate with the pioneer and grow along the same pathway.

\section{Genes involved in regulating axonal guidance at the midline}

In all animals with a bilaterally symmetrical nervous system, the midline has been shown to be a critical axonal choice point where axons choose to remain on the same side of the organism and project ipsilaterally or to cross the midline and project contralaterally. Much of what we know molecularly about how this axonal decision is made comes from studies in Drosophila melanogaster. The Drosophila nerve cord consists of two bilateral tracts of axons running anteroposteriorly on either side of the midline with intermittent axonal projections crossing the midline between these two tracts (the contralaterally projecting axons) to enter the opposite tract. Work in the last decade has shown that glial cells positioned at the midline produce a number of different molecules that regulate axonal pathfinding at the midline and determine which axons will project ipsilaterally and which will project contralaterally. Two molecules have been shown to be critical in this decision, the chemorepellent molecule, Slit, and its receptors, the roundabout (or Robo) family (33$35)$. These molecules have been highly conserved during evolution (36-38) and although they exhibit some functional differences in vertebrates they also have some striking similarities (39, reviewed in Ref. 40). Slit and Robo operate in the development of the mammalian corpus callosum and will be discussed further below.

\section{Midline glial populations involved in guiding callosal axons}

At the midline, the axons of the corpus callosum cross between the two cerebral hemispheres in a region called the massa commissuralis (41), a region of cellular continuity within the interhemispheric fissure. Cells generated in the medial aspect of the lateral ventricles migrate medially within this region to form a bridge between the two hemispheres called the "glial sling" (42). Evidence that the glial sling cells are required for the formation of the corpus callosum comes from two types of experiments: i) either failure of the glial sling cells to migrate to the midline $(43,44)$ or lesions of the glial sling (42) preventing the formation of the corpus callosum, and ii) in acallosal animals the formation of the corpus callosum can be "rescued" when cellulose membranes coated with glial cells are inserted into the midline (45). However, nothing is known about the molecules required for glial sling development or what molecules the glial sling cells produce that guide cortical axons. Furthermore, the cells that make up the glial sling do not possess many of the characteristics of mature glia: principally they do not express glial fibrillary acidic protein (GFAP).

GFAP is an intermediate filament protein and the most widely used marker of astrocytic glial cells. Until recently, glial cells were thought to arise during development from E16.5 in mice and rats (46-48). However, studies in which the reporter gene lacZ was placed under the control of the GFAP promoter have shown that glial cells may be present as early as E13 in the mouse telencephalon (49). In this study, the expression of the transgene was confirmed to be within astrocytes by electron microscopy.

Midline glia have been shown to be associated with the formation of other commissural projections in the brain (50), such as the anterior commissure $(51,52)$ and the optic chiasm 
(53-55; reviewed in Refs. 56 and 57).

Since the glial sling is not GFAP positive and given the early expression of the lacZ transgene in the GFAP-lacZ mice, we decided to re-examine when glial cells first differentiated at the midline of the developing cerebral cortex. We found two midline glial structures, the glial wedge and glia within the indusium griseum, which expressed a guidance activity for callosal axons (58). Glial wedge cell bodies develop in the ventricular zone of the lateral ventricles at the corticoseptal boundary and send long radial-glial-like processes toward the midline. They first express GFAP at E13, and by E15 these processes form a wedge-shaped structure directly ventral to where the corpus callosum will form (58). Glia within the indusium griseum develop directly dorsal to the developing corpus callosum. The indusium griseum lies directly above the corpus callosum at the ventral part of the cingulate cortex. The indusium griseum is made up of many of the same cell types as the hippocampus, and has a similar layered structure (59). The indusium griseum receives direct inputs from the olfactory bulb and therefore may constitute a pathway involved in olfactory memory (60). Glia have previously been observed within this region after birth $(61,62)$, but we observed GFAP-positive cells within this region as early as E17. Although the indusium griseum is a small structure when viewed in coronal sections it is present above the entire rostrocaudal extent of the corpus callosum $(60,61)$. In collagen gels, glial wedge explants secrete a short range diffusible repellent/growth suppressive molecule and in organotypic slices reorientation of the glial wedge and glia within the indusium griseum causes callosal axons to turn away from the midline (58). Furthermore, when these glial structures are excised and replaced by cortical grafts that do not contain midline glia, callosal axons fail to turn and cross the midline and instead grow aberrantly into the septum (58).

\section{Pioneering axons in the development of the corpus callosum}

Pioneering axons are the first axons to grow along a specific trajectory. Later developing axons follow their lead by fasciculating with the pioneering axon. Evidence for the role of pioneering axons in guiding later developing axons to their target has come from ablation experiments in grasshoppers (63), zebrafish (64) and mammals $(65,66)$. These experiments show that in the absence of the pioneering axons, later arriving axons are unable to find their correct path of growth.

The cingulate cortex sends the first axons across the cortical midline $(67,68)$ at E17 in the rat and E15.5 in the mouse. However, a recent study suggested that the cingulate axons do not pioneer the corpus callosum and instead project to the contralateral hippocampus (68). This study also suggested that the pioneering neurons for the corpus callosum were located in the rostrolateral neocortex. However, in both previous studies $(67,68)$, this pathway was investigated using retrograde labeling techniques that label a single projection in isolation. Given this controversy, we decided to investigate the origin of the callosal pioneers using anterograde labeling of the axons (69). To do this we made small injections of DiI in the cingulate cortex and DiA in the neocortex. We found that at embryonic day 15 DiI axons projected to three different regions: across the midline into the contralateral cortex, into the fornix, and ventrally into the medial septa. At later ages these pathways become even more distinct.

To determine if cingulate axons projected to the hippocampus, we injected DiI in the cingulate cortex to label axons crossing the midline and DiA in the hippocampus to retrogradely label neurons in the cingulate cortex. We found that only a small population of cingulate neurons projected to the ipsilateral hippocampus (69). This result suggested that in the earlier experiments of Koester and 
O'Leary (67) it was highly unlikely that neurons in the cingulate cortex had been retrogradely labeled via the hippocampal commissure.

We also wanted to determine if the cingulate axons may act as pioneering axons for the corpus callosum. To investigate this we labeled the cingulate cortex with DiI and the rostrolateral neocortex with $\mathrm{DiA}$ in the same brain. In every case we found that the cingulate axons crossed the midline first, followed by the neocortical axons. In fact, the neocortical axons grew across the midline within the bundle of DiI-labeled cingulate axons. Interestingly, in the same experiments we observed a large number of cingulate axons projecting laterally toward the rostrolateral neocortex as early as E15. Our working hypothesis is that neurons within the cingulate cortex that project laterally may provide guidance for neocortical axons projecting toward the midline, and once they reach the midline, cingulate axons that project medially may provide guidance for neocortical axons to cross the midline (69).

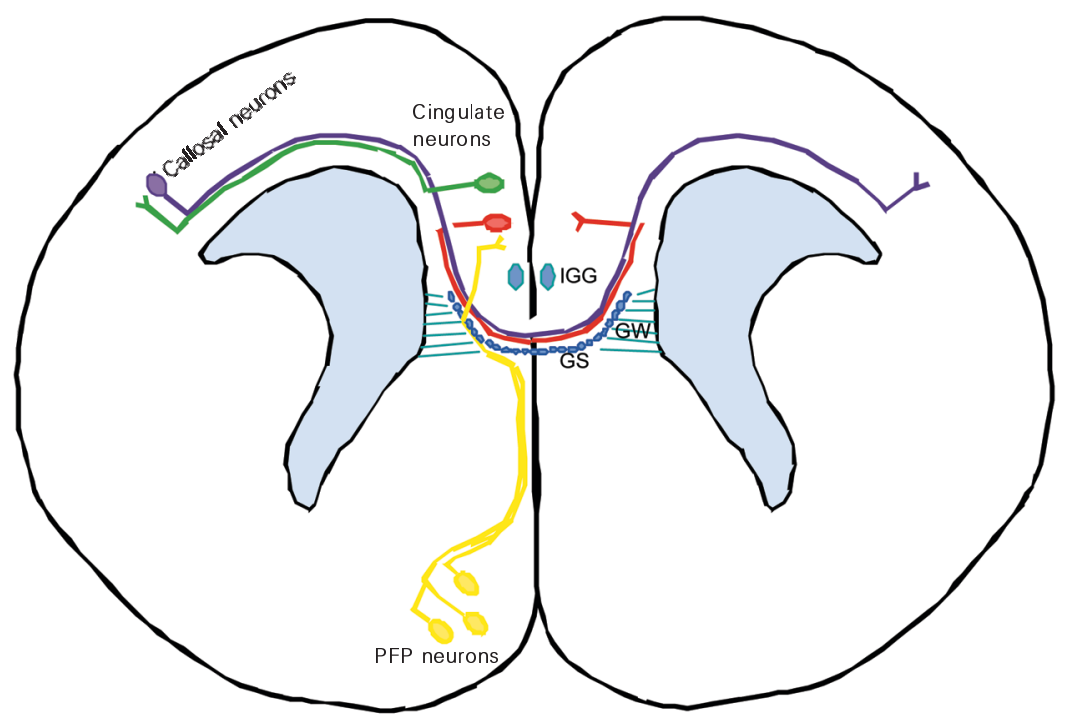

Figure 2. Axonal and glial populations at the cortical midline. Shown is a schematic view of a coronal section through the developing cortex at E17. A callosal neuron is shown in purple and neurons of the perforating pathway (PFP) are shown in yellow. Cingulate pioneering neurons projecting laterally are shown in green and projecting medially are shown in red. $\mathrm{GW}=$ glial wedge; $\mathrm{GS}=$ glial sling; $\mathrm{IGG}=$ indusium griseum glia .

\section{Development of the perforating pathway}

As previously described, the midline is a choice point for developing axons. A fundamental choice axons make at the midline is whether to remain ipsilateral or to project across the midline to the contralateral hemisphere. At the developing cortical midline, another axonal population is present but remains ipsilateral. This pathway is called the perforating pathway (70) and is made up of neurons projecting between the medial septum and the diagonal band of Broca, and the cingulate cortex (71). The pioneering axons of the perforating pathway reach the midline at E15, around the same time the pioneering axons of the corpus callosum are crossing the midline. This indicates that differential guidance mechanisms must be operating during the formation of these two pathways at the same stage of development. In Drosophila this is regulated by the protein Commissureless (72), which is able to downregulate Robo expression on contralaterally projecting axons. At the developing rodent cortical midline, the guidance of the ipsilateral and contralateral axons is different. The perforating pathway axons do not express Robo, therefore their guidance cannot be regulated by Slit. The contralaterally expressing axons respond to Slit in order to cross the midline rather than being repelled away from the midline after crossing (58).

We are still a long way from understanding how the corpus callosum develops normally and what goes wrong in cases of ACC. Clearly, midline glial populations are important in callosal development. The role of pioneering axons needs to be further tested and the molecules involved identified. Figure 2 summarizes the midline glial structures and pioneering axon populations associated with development of the corpus callosum. How these guidance mechanisms work together and what molecular pathways are involved is the current exciting challenge for this field. 


\section{References}

1. Polleux F, Giger RJ, Ginty DD, Kolodkin AL \& Ghosh A (1998). Patterning of cortical efferent projections by semaphorinneuropilin interactions. Science, 282: 1904-1906.

2. Jeret JS, Serur D, Wisniewski KE \& Lubin RA (1987). Clinicopathological findings associated with agenesis of the corpus callosum. Brain and Development, 9: 255264.

3. Fazeli A, Dickinson SL, Hermiston ML, Tighe RV, Steen RG, Small CG, Stoeckli ET, Keino-Masu K, Masu M, Rayburn H, Simons J, Bronson RT, Gordon JI, TessierLavigne M \& Weinberg RA (1997). Phenotype of mice lacking functional Deleted in colorectal cancer (Dcc) gene. Nature, 386: 796-804.

4. Orioli D, Henkemeyer M, Lemke G, Klein R \& Pawson T (1996). Sek4 and Nuk receptors cooperate in guidance of commissural axons and in palate formation. EMBO Journal, 15: 6035-6049.

5. Henkemeyer M, Orioli D, Henderson JT, Saxton TM, Roder J, Pawson T \& Klein R (1996). Nuk controls pathfinding of commissural axons in the mammalian central nervous system. Cell, 86: 35-46.

6. Serafini $T$, Colamarino $S A$, Leonardo ED, Wang $H$, Beddington R, Skarnes WC \& Tessier-Lavigne M (1996). Netrin-1 is required for commissural axon guidance in the developing vertebrate nervous system. Cell, 87: 1001-1014.

7. Bagri A, Marin O, Plump AS, Mak J, Pleasure SJ, Rubenstein JL \& Tessier-Lavigne $M$ (2002). Slit proteins prevent midline crossing and determine the dorsoventral position of major axonal pathways in the mammalian forebrain. Neuron, 33: 233248.

8. Qiu M, Anderson S, Chen S, Meneses JJ, Hevner R, Kuwana E, Pedersen RA \& Rubenstein JL (1996). Mutation of the Emx-1 homeobox gene disrupts the corpus callosum. Developmental Biology, 178: 174-178.

9. Yoshida M, Suda Y, Matsuo I, Miyamoto N, Takeda N, Kuratani S \& Aizawa S (1997). Emx1 and Emx2 functions in development of dorsal telencephalon. Development, 124: 101-111.

10. Pellegrini M, Mansouri A, Simeone A, Boncinelli E \& Gruss P (1996). Dentate gyrus formation requires Emx2. Development, 122: 3893-3898.

11. Dattani MT, Martinez-Barbera JP, Thomas $P Q$, Brickman JM, Gupta R, Martensson
IL, Toresson H, Fox M, Wales JK, Hindmarsh PC, Krauss S, Beddington RS \& Robinson IC (1998). Mutations in the homeobox gene HESX1/Hesx1 associated with septo-optic dysplasia in human and mouse. Nature Genetics, 19: 125-133.

12. das Neves $L$, Duchala CS, Tolentino-Silva F, Haxhiu MA, Colmenares C, Macklin WB, Campbell CE, Butz KG, Gronostajski RM \& Godinho F (1999). Disruption of the murine nuclear factor I-A gene (Nfia) results in perinatal lethality, hydrocephalus, and agenesis of the corpus callosum. Proceedings of the National Academy of Sciences, USA, 96: 11946-11951.

13. Stoykova A, Fritsch $R$, Walther $C$ \& Gruss $P$ (1996). Forebrain patterning defects in Small eye mutant mice. Development, 122: 3453-3465.

14. Bertuzzi S, Hindges R, Mui SH, O'Leary DD \& Lemke G (1999). The homeodomain protein vax 1 is required for axon guidance and major tract formation in the developing forebrain. Genes and Development, 13: 3092-3105.

15. Scotland $P$, Zhou $D$, Benveniste $H$ \& Bennett $V$ (1998). Nervous system defects of AnkyrinB (-/-) mice suggest functional overlap between the cell adhesion molecule L1 and 440-kD AnkyrinB in premyelinated axons. Journal of Cell Biology, 143: 1305-1315.

16. Demyanenko GP, Tsai AY \& Maness PF (1999). Abnormalities in neuronal process extension, hippocampal development, and the ventricular system of $\mathrm{L} 1$ knockout mice. Journal of Neuroscience, 19: 49074920.

17. Muller U, Cristina N, Li ZW, Wolfer DP, Lipp HP, Rulicke T, Brandner S, Aguzzi A \& Weissmann C (1994). Behavioral and anatomical deficits in mice homozygous for a modified beta-amyloid precursor protein gene. Cell, 79: 755-765.

18. Magara F, Muller U, Li ZW, Lipp HP, Weissmann C, Stagljar M \& Wolfer DP (1999). Genetic background changes the pattern of forebrain commissure defects in transgenic mice underexpressing the beta-amyloid-precursor protein. Proceedings of the National Academy of Sciences, USA, 96: 4656-4661.

19. Rudolph $D$, Tafuri $A$, Gass $P$, Hammerling GJ, Arnold B \& Schutz G (1998). Impaired fetal T cell development and perinatal lethality in mice lacking the CAMP response element binding protein. Proceedings of the National Academy of Sciences, USA,
95: 4481-4486.

20. Shen Y, Mani S, Donovan SL, Schwob JE \& Meiri KF (2002). Growth-associated protein-43 is required for commissural axon guidance in the developing vertebrate nervous system. Journal of Neuroscience, 22: 239-247.

21. Meixner A, Haverkamp S, Wassle $H$, Fuhrer S, Thalhammer J, Kropf N, Bittner RE, Lassmann $H$, Wiche $G$ \& Propst $F$ (2000). MAP1B is required for axon guidance and is involved in the development of the central and peripheral nervous system. Journal of Cell Biology, 151: 11691178.

22. Stumpo DJ, Bock CB, Tuttle JS \& Blackshear PJ (1995). MARCKS deficiency in mice leads to abnormal brain development and perinatal death. Proceedings of the National Academy of Sciences, USA, 92: 944-948.

23. Wu M, Chen DF, Sasaoka T \& Tonegawa $S$ (1996). Neural tube defects and abnormal brain development in F52-deficient mice. Proceedings of the National Academy of Sciences, USA, 93: 2110-2115.

24. Lanier LM, Gates MA, Witke W, Menzies AS, Wehman AM, Macklis JD, Kwiatkowski D, Soriano P \& Gertler FB (1999). Mena is required for neurulation and commissure formation. Neuron, 22: 313-325.

25. Chae T, Kwon YT, Bronson R, Dikkes P, Li E \& Tsai LH (1997). Mice lacking p35, a neuronal specific activator of $\mathrm{Cdk} 5$, display cortical lamination defects, seizures, and adult lethality. Neuron, 18: 29-42.

26. Brouns MR, Matheson SF, Hu KQ, Delalle I, Caviness VS, Silver J, Bronson RT \& Settleman J (2000). The adhesion signaling molecule p190 RhoGAP is required for morphogenetic processes in neural development. Development, 127: 48914903.

27. Meyers EN, Lewandoski M \& Martin GR (1998). An Fgf8 mutant allelic series generated by Cre- and Flp-mediated recombination. Nature Genetics, 18: 136-141.

28. Ni W, Rajkumar K, Nagy JI \& Murphy LJ (1997). Impaired brain development and reduced astrocyte response to injury in transgenic mice expressing IGF binding protein-1. Brain Research, 769: 97-107.

29. Goodhill GJ \& Urbach JS (1999). Theoretical analysis of gradient detection by growth cones. Journal of Neurobiology, 41: 230-241.

30. Tessier-Lavigne M \& Goodman CS (1996). The molecular biology of axon guidance. 
Science, 274: 1123-1133.

31. de la Torre JR, Hopker VH, Ming GL, Poo MM, Tessier-Lavigne M, HemmatiBrivanlou A \& Holt CE (1997). Turning of retinal growth cones in a netrin-1 gradient mediated by the netrin receptor DCC. Neuron, 19: 1211-1224.

32. Song HJ, Ming GL \& Poo MM (1997). cAMP-induced switching in turning direction of nerve growth cones. Nature, 388: 275-279.

33. Kidd T, Brose K, Mitchell KJ, Fetter RD, Tessier-Lavigne M, Goodman CS \& Tear $G$ (1998). Roundabout controls axon crossing of the CNS midline and defines a novel subfamily of evolutionarily conserved guidance receptors. Cell, 92: 205215.

34. Kidd T, Bland KS \& Goodman CS (1999). Slit is the midline repellent for the robo receptor in Drosophila. Cell, 96: 785-794.

35. Rajagopalan S, Nicolas E, Vivancos V, Berger J \& Dickson BJ (2000). Crossing the midline: roles and regulation of Robo receptors. Neuron, 28: 767-777.

36. Brose $K$, Bland KS, Wang KH, Arnott D, Henzel W, Goodman CS, Tessier-Lavigne M \& Kidd T (1999). Slit proteins bind Robo receptors and have an evolutionarily conserved role in repulsive axon guidance. Cell, 96: 795-806.

37. Wang KH, Brose $K$, Arnott $D$, Kidd $T$, Goodman CS, Henzel W \& TessierLavigne M (1999). Biochemical purification of a mammalian slit protein as a positive regulator of sensory axon elongation and branching. Cell, 96: 771-784.

38. Li HS, Chen JH, Wu W, Fagaly T, Zhou L, Yuan W, Dupuis S, Jiang ZH, Nash W, Gick C, Ornitz DM, Wu JY \& Rao Y (1999). Vertebrate slit, a secreted ligand for the transmembrane protein roundabout, is a repellent for olfactory bulb axons. Cell, 96: 807-818.

39. Plump AS, Erskine L, Sabatier C, Brose K, Epstein CJ, Goodman CS, Mason CA \& Tessier-Lavigne M (2002). Slit1 and Slit2 cooperate to prevent premature midline crossing of retinal axons in the mouse visual system. Neuron, 33: 219-232.

40. Richards LJ (2002). Surrounded by Slit how forebrain commissural axons can be led astray. Neuron, 33: 153-155.

41. Rakic P \& Yakolev PI (1968). Development of the corpus callosum and cavum septi in man. Journal of Comparative Neurology, 132: 45-72.

42. Silver J, Lorenz SE, Wahlsten D \& Coughlin J (1982). Axonal guidance during development of the great cerebral commissures: Descriptive and experi- mental studies, in vivo, on the role of preformed glial pathways. Journal of Comparative Neurology, 210: 10-29.

43. Schneider BF \& Silver J (1990). Failure of the subcallosal sling to develop after embryonic X-irradiation is correlated with absence of the cavum septi. Journal of Comparative Neurology, 299: 462-469.

44. Wahlsten D (1987). Defects of the fetal forebrain in mice with hereditary agenesis of the corpus callosum. Journal of Comparative Neurology, 262: 227-241.

45. Silver J \& Ogawa MY (1983). Postnatally induced formation of the corpus callosum in acallosal mice on glia-coated cellulose bridges. Science, 220: 1067-1069.

46. Bovolenta $P$, Liem RKH \& Mason CA (1987). Glial filament protein expression in astroglia in the mouse visual pathway. Developmental Brain Research, 33: 113126.

47. Hirano M \& Goldman JE (1988). Gliogenesis in rat spinal cord: evidence for origin of astrocytes and oligodendrocytes from radial precursors. Journal of Neuroscience Research, 21: 155-167.

48. Landry CF, Ivy GO \& Brown IR (1990). Developmental expression of glial fibrillary acidic protein mRNA in the rat brain analyzed by in situ hybridization. Journal of Neuroscience Research, 25: 194-203.

49. Brenner M, Kisseberth WC, Su Y, Besnard F \& Messing A (1994). GFAP promoter directs astrocyte-specific expression in transgenic mice. Journal of Neuroscience, 14: 1030-1037

50. Silver J, Edwards MA \& Levitt $P$ (1993). Immunocytochemical demonstration of early appearing astroglial structures that form boundaries and pathways along axon tracts in the fetal brain. Journal of Comparative Neurology, 328: 415-436.

51. Cummings DM, Malun D \& Brunjes $P C$ (1997). Development of the anterior commissure in the opossum: midline extracellular space and glia coincide with early axon decussation. Journal of Neurobiology, 32: 403-414.

52. Pires-Neto $M$, Braga-De-Souza $S$ \& Lent $R$ (1998). Molecular tunnels and boundaries for growing axons in the anterior commissure of hamster embryos. Journal of Comparative Neurology, 399: 176-188.

53. Reese BE, Maynard TM \& Hocking DR (1994). Glial domains and axonal reordering in the chiasmatic region of the developing ferret. Journal of Comparative Neurology, 349: 303-324.

54. Marcus RC, Blazeski R, Godement P \& Mason CA (1995). Retinal axon divergence in the optic chiasm: uncrossed axons diverge from crossed axons within a midline glial specialization. Journal of Neuroscience, 15: 3716-3729.

55. Wang LC, Dani J, Godement P, Marcus RC \& Mason CA (1995). Crossed and uncrossed retinal axons respond differently to cells of the optic chiasm midline in vitro. Neuron, 15: 1349-1364.

56. Godement P \& Mason CA (1993). Guidance of retinal fibers in the optic chiasm. Perspectives on Developmental Neurobiology, 1: 217-225.

57. Silver J (1993). Glia-neuron interactions at the midline of the developing mammalian brain and spinal cord. Perspectives on Developmental Neurobiology, 1: 227-236.

58. Shu T \& Richards LJ (2001). Cortical axon guidance by the glial wedge during development of the corpus callosum. Journal of Neuroscience, 21: 2749-2758.

59. Wyss JM \& Sripanidkulchai K (1983). The indusium griseum and anterior hippocampal continuation in the rat. Journal of Comparative Neurology, 219: 251-272.

60. Adamek GD, Shipley MT \& Sanders MS (1984). The indusium griseum in the mouse: architecture, Timm's histochemistry and some afferent connections. Brain Research Bulletin, 12: 657-668.

61. Sturrock RR (1978). Development of the indusium griseum. I. A quantitative light microscopy study of neurons and glia. Journal of Anatomy, 125: 293-298.

62. Sturrock RR (1978). Development of the indusium griseum. II. A semi-thin light microscope and electron microscope study. Journal of Anatomy, 125: 433-445.

63. Klose M \& Bentley D (1989). Transient pioneer neurons are essential for formation of an embryonic peripheral nerve. Science, 245: 982-984.

64. Kuwada J (1986). Cell recognition by neuronal growth cones in a simple vertebrate embryo. Science, 233: 740-746.

65. Ghosh A, Antonini A, McConnell SK \& Shatz CJ (1990). Requirement for subplate neurons in the formation of thalamocortical connections. Nature, 347: 179181.

66. Ghosh A \& Shatz CJ (1993). A role for subplate pioneers in the patterning of connections from thalamus to neocortex. Development, 117: 1031-1047.

67. Koester SE \& O'Leary DDM (1994). Axons of early generated neurons in cingulate cortex pioneer the corpus callosum. Journal of Neuroscience, 14: 6608-6620.

68. Ozaki HS \& Wahlstein D (1998). Timing and origin of the first cortical axons to project through the corpus callosum and the subsequent emergence of callosal 
projection cells in mouse. Journal of Comparative Neurology, 400: 197-206.

69. Rash BG \& Richards LJ (2001). A role for cingulate pioneering axons in the development of the corpus callosum. Journal of Comparative Neurology, 434: 147-157.

70. Hankin MH \& Silver J (1988). Development of intersecting CNS fiber tracts: the corpus callosum and its perforating fiber pathway. Journal of Comparative Neurology, 272: 177-190.

71. Shu T, Shen WB \& Richards LJ (2001). Development of the perforating pathway: an ipsilaterally projecting pathway between the medial septum/diagonal band of Broca and the cingulate cortex that intersects the corpus callosum. Journal of Comparative Neurology, 436: 411-422.

72. Tear G, Harris R, Sutaria S, Kilomanski K, Goodman CS \& Seeger MA (1996). Commissureless controls growth cone guidance across the CNS midline in Drosophila and encodes a novel membrane protein. Neuron, 16: 501-514. 